\title{
FORUM
}

\section{Trichogramma in Brazil: Feasibility of Use after Twenty Years of Research}

\author{
José R.P. PARRa And Roberto A. ZuCChi \\ Depto. Entomologia, Fitopatologia e Zoologia Agrícola, ESALQ/USP, C. postal 9, 13418-900, Piracicaba, SP
}

Neotropical Entomology 33(3):271-281 (2004)

Trichogramma no Brasil: Viabilidade de Uso Após Vinte Anos de Pesquisa

\begin{abstract}
RESUMO - São apresentados os resultados dos estudos com Trichogramma no Brasil, especialmente aqueles desenvolvidos na ESALQ/USP, nas últimas duas décadas (1984-2004). O projeto, envolvendo desde a taxonomia, técnicas de criação, aspectos biológicos e comportamentais das pragas e dos parasitóides, dinâmica populacional das pragas, técnicas de liberação,estudos de seletividade, avaliação da eficiência, pode ser considerado um modelo e foi seguido por outros programas de controle biológico no Brasil e na América Latina. O programa gerou inúmeras publicações, permitindo a formação de recursos humanos na área, abrindo novas áreas de pesquisa e mostrando que o parasitóide pode ser usado no controle de pragas-chave do algodoeiro, cana-de-açúcar, grãos armazenados, hortaliças, milho, soja e tomateiro. As perspectivas do uso do parasitóides possibilitaram a criação de empresas para comercializá-los no Brasil, transferindo mais facilmente a tecnologia ao usuário.
\end{abstract}

PALAVRAS-CHAVE: Trichogrammatidae, parasitóide de ovos, controle biológico aplicado

ABSTRACT - Results of studies with Trichogramma in Brazil are presented, especially those developed at ESALQ/USP in the past two decades (1984-2004). The project involved taxonomy, rearing techniques, biological and behavioral aspects of the pests and parasitoids, pest population dynamics, release techniques, selectivity studies, and efficiency evaluation. It can be considered a model project and has been adopted by other biological control programs in Brazil and Latin America. The program has given rise to a number of publications, allowing the formation of human resources in this area and opening new research areas. The results indicated that the parasitoid can be used to control key pests in cotton, sugarcane, stored grain, vegetables, corn, soybean, and tomato. The perspective of using the parasitoid has stimulated the creation of companies to commercialize it in Brazil, thus more easily transferring this technology to users.

KEY WORDS: Trichogrammatidae, egg parasitoid, applied biological control

Trichogramma species (Fig. 1) are among the most reared and used natural enemies in the world. Every year, they are released in more than 16 million ha, in annual (for the most part) and perennial crops (Hassan 1997, van Lenteren 2000), even though Smith (1996) had reported their use in 32 million ha. Worldwide, 28 Trichogramma species are released in 28 crops (Hassan 1988). These are among the most frequently studied insects, with several books published about their efficiency in biological control (Wajnberg \& Hassan 1994, Parra \& Zucchi 1997).

Studies on Trichogramma began in the last century, when Flanders (1927) discovered the possibility of rearing it on a factitious host, Sitotroga cerealella (Oliv.). Since then, there has been great interest in the parasitoid, because of its efficiency and ease of multiplication. In Brazil, studies began in the 1940's to control Neoleucinodes elegantalis (Guenée) in tomato (Gomes 1963). Papers by Moraes et al. (1963) came next, targeted at forest lepidopterans.
In the $20^{\text {th }}$ century, since the researches by Flanders (1927), several countries, especially the USA, started to use it. However, these initial programs were in general inadequatelyplanned and isolated projects without inter- and multidisciplinary characteristics. Thus, many errors were committed and the expected efficiency was not achieved because of a lack of knowledge or misevaluation of the following items: (1) egg density of the target pest; (2) Trichogramma species unsuitable for controlling the target pest; (3) quality control of the parasitoid produced; (4) number of parasitoids released, and form of release; (5) pest dynamics and phenology of the plant; (6) competition with other biological control agents; (7) effect of chemical products (selectivity) on Trichogramma in crops where several pests occurred (Parra et al. 2002). These errors led this egg parasitoid to be discredited with regard to its efficiency. However, some important findings in the 1970's, such as the use of male genitalia for species identification (Nagarkati \& Nagaraja 

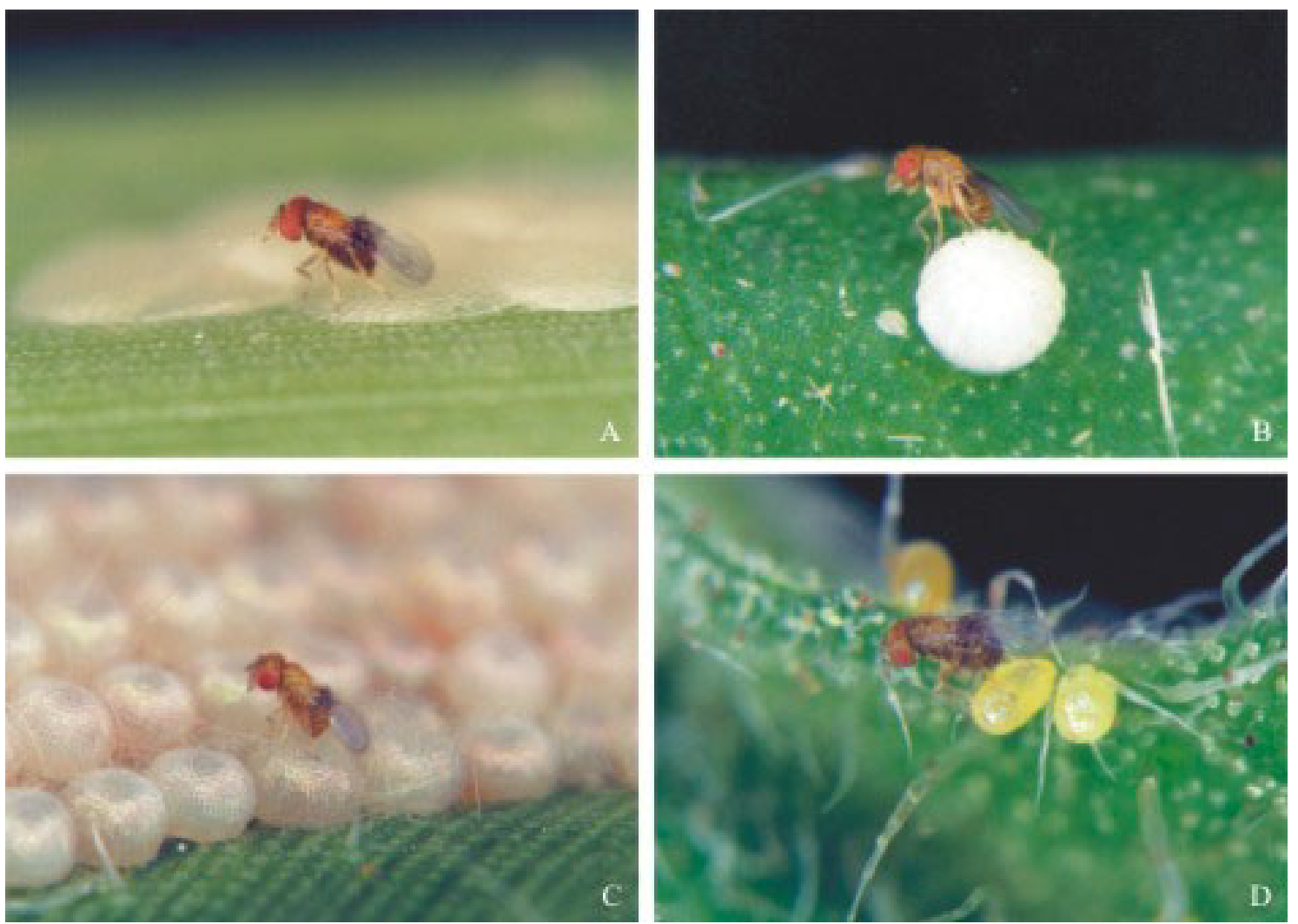

Figure 1. Trichogramma on eggs of agricultural pests. A) D. saccharalis; B) H. virescens; C) S. frugiperda; D) T. absoluta.

1971) and the use of Anagasta kuehniella (Zeller), which was nutritionally more suitable than the moth $S$. cerealella used until then (Lewis et al. 1976), allowed a reflexion on the use of this parasitoid. With support from IOBC and from Trichogramma work groups, studies were resumed worldwide, under a more modern and adequate view concerning the reality of those times.

Biological control programs for agricultural pests in Brazil began with Jean Voegelé (INRA, Antibes), one of the leaders in studies involving Trichogramma in the 1980's, who taught courses in Brazil, encouraging Brazilian researchers to develop researches with Trichogramma. The interest in developing studies with this egg parasitoid was sparked at ESALQ (Entomology) and, in 1982, the senior author of this work (JRPP) visited the INRA and, in 1984, together with a group of researchers and with the support from a taxonomist (RAZ), the program was started, based on the French model, primarily targeted at the control of Diatraea saccharalis (Fabr.) in sugarcane and Heliothis virescens (Fabr.) and Alabama argillacea (Hueb.) in cotton. This program involved the following stages: collection, identification and maintenance of Trichogramma spp. strains; selection of a factitious host for the mass rearing of the parasitoid; biological and behavioral aspects of Trichogramma spp.; egg dynamics of the target pest; parasitoid release, number of released parasitoids and release points; season and form of release; selectivity of agrochemicals; efficiency evaluation; pest/ parasitoid simulation model.
The objective of this paper is to show the advances that occurred 20 years after the program was started, the example followed by other biological control programs, publications produced, human resources formed, new research areas that were initiated in the country, as well as the feasibility to use the parasitoid on different crops in Brazil.

\section{Studies on Trichogramma}

Collection, Identification and Maintenance of Trichogramma Strains. Until the 1970's, since Trichogramma was considered nonspecific, individuals of a given species, collected in areas with different climatic characteristics, were used to control pests in geographically distinct regions. Currently, microclimatic specificities are admitted within the same species. For this reason, it is essential to maintain properly labeled, separate strains in the laboratory, in order to ensure the genetic heritage of the initial population.

The presence of a taxonomist is indispensable for this type of program, since an erroneous identification or the lack of it could result in failure of the program. A collection of strains exists at ESALQ, collected from different points of the country. This collection must be supervised by a taxonomist to avoid errors common in the past.

T. minutum Riley was, for a long time, referred as the species parasitizing D. saccharalis in Brazil. Today, it is known that this species does not occur in Brazil (Parra \& Zucchi 1986). Due to the minute size of Trichogramma species $(0.20$ 
$\mathrm{mm}$ ), precautions must be taken, such as maintaining the rearing at separate locations; if this measure is neglected, interspecific competition may occur, with predominance of the most aggressive species (Parra et al. 2002).

There are about 200 species of Trichogramma described worldwide (Pinto 1999). In Brazil, 28 species have been recorded, of which one half were described during the studies conducted at ESALQ (Zucchi 1988; Querino \& Zucchi 2003 $a, b)$, the characterization of several species based on morphology (Querino \& Zucchi 2002 a,b) and on molecular techniques (Ciociola et al. $2001 \mathrm{a}, \mathrm{b}, \mathrm{c}$ ). The most recent list of Trichogramma species in Brazil and their corresponding hosts was prepared by Zucchi \& Monteiro (1997). Information about the species contained in the collection at ESALQ is available on the web (Querino \& Zucchi 2001).

Selection of Factitious Hosts for Mass Rearing of Parasitoids. Even though several factitious hosts exist for rearing Trichogramma, many researchers still prefer to use $S$. cerealella, because it is easy to rear, despite being less adequate for the multiplication of the parasitoid in relation to other species, such as A. kuehniella and Corcyra cephalonica (Stainton) (Lewis et al. 1976; Parra et al. 1991, 1997; Gomes 1997; Gomes \& Parra 1998; Bernardi et al. 2000). In order to compensate for this lower nutritional quality, $T$. pretiosum Riley reared on $S$. cerealella should be released in greater numbers (in relation to those reared on C. cephalonica and $A$. kuehniella) to control $H$. virescens in cotton.

Therefore, it is essential to associate the nutritional quality of the host, to produce parasitoids that are competitive with those in nature, with a rearing technique that enables mass production of Trichogramma. Since the Chinese have extensive silkworm rearing at their disposal, they also use Philosamia ricini (Drury) and Antheraea pernyi (GuérinMéneville) eggs or ovules in Trichogramma rearing.

In general, A. kuehniella has proved to be the most suitable factitious host for the Brazilian species (Parra et al. 1991, Gomes \& Parra 1998), although, according to Gomes (1997), C. cephalonica is the best rearing host for T. galloi Zucchi, a predominant parasitoid of $D$. saccharalis eggs in most of Brazil.

The influence of biotic (mating, oviposition, adult feeding) and abiotic factors (temperature, relative humidity, and photoperiod) was exhaustively studied in a number of papers and book chapters published on the subject (Parra 2002).

Biological and Behavioral Aspects of Trichogramma spp. Basic studies were conducted for the main Trichogramma species collected in Brazil, such as strain selection, temperature requirements for laboratory production and for insect adaptation in the field, humidity requirements, determination of the most suitable parasitoid:host eggs ratio, adaptation to the factitious host (number of generations to achieve it), parasitism capacity, and behavior. In recent years, the findings that Trichogramma has only a single instar (Volkoff et al. 1995, Dahlan \& Gordh, 1996) and the influence of symbionts, especially Wolbachia, on the sex ratio of Trichogramma (Stouthamer et. al. 1990), have been taken into account without, however, forsaking the classic papers by Lund (1934), Doutt (1959), Buttler \& Lopes (1980), and
Calvin et al. (1984), among others.

Quality control must be a constant procedure in laboratory populations, as well as the periodic introduction of wild populations and even rearing the parasitoid on the natural host after a number of generations have been reared on the factitious host. T. pretiosum populations can withstand high inbreeding rates in laboratory rearing, without showing evidence in their biological characteristics of degenerative reflexes that would compromise their quality (Prezotti et al. 2004).

Egg Dynamics of Target Pests. This has been one of the leaststudied items in our country, albeit essential for defining the season when the parasitoid should be released, i.e., at the onset of the population of adults and, consequently, of eggs. There have been attempts to use the plant's phenology as groundwork for parasitoid release (Lopes 1988); all other studies are based on the pest's dynamics with the use of pheromoneE. aurantiana (Lima) - or through the on-site evaluation of the plant structure that harbors eggs (most crops).

Parasitoid Release: Numbers, Places, Seasons and Ways. Once the release season has been defined, the parasitoid's dispersal ability must be evaluated (Lopes 1988, Sá et al. 1993, Zachrisson \& Parra 1998) to determine the number of release points. The form of release can be very simple, such as releasing the emerged adults from plastic or glass containers by walking through the field, or in a more sophisticated manner, by airplane, using starch capsules (biodegradable) which allow the parasitoids to exit but prevent predation (patented by the INRA, France). In Brazil, "Bug Agentes Biológicos" (an insect-selling company) has developed a similar capsule, which has been largely used. One of the great problems in tropical countries is the predation of pupae after release. Thus, the action of predators must be taken into account when Trichogramma is released in the form of pupae (Pinto 1999). Releases using a center pivot were used in Brazil for T. pretiosum in tomato (Haji et al. 2002).

The number of parasitoids to be released must be defined in laboratory, semi field, and field tests. In sugarcane, Lopes (1988) estimated the proportion of 1.6 parasitoid (Trichogramma spp.) per egg of the pest as ideal. Sá (1991) found a ratio of 10.7 T. pretiosum per egg of Helicoverpa zea (Boddie) in corn, while Zachrisson (1997) found a 5.3 ratio of $T$. pretiosum per Anticarsia gemmatalis (Hueb.) egg in soybean. In perennial crops, this number can be quite higher (36 parasitoids per egg for the citrus fruit borer, E. aurantiana) (Molina 2003). In general, the literature has recorded, in citrus and other fruit crops, releases varying from 70,000 to 3.8 million parasitoids/ha, or 9,000 to 50,000 parasitoids/plant (Oatman \& Platner 1985, Hassan et al. 1988, Newton \& Odendaal 1990, Glen \& Hoffmann 1997, Mills et al. 2000). In many countries, fixed numbers of parasitoids are released for the sake of ease, regardless of the existing population of the pest. This could be one of the reasons for the lack of success of the parasitoid.

Egg parasitism by Trichogramma on different days in the same release card can extend the period of action of the parasitoid (Pinto 1999). 
Selectivity of Agrochemicals. In crops that have a large number of pests and require the application of agrochemicals, selectivity studies must be done to establish an interval between parasitoid release and the application of such products. These selectivity tests must be based on IOBC rules to allow comparisons with other countries (Hassan 1997). Only a few papers on selectivity have been done in Brazil (Foerster 2002, Degrande et al. 2002).

Efficiency Evaluation. Efficiency and cost must be compatible with the crop and comparable to traditional control methods. Thus, a crop such as tomato, with high profitability, allows up to 10 Trichogramma releases per crop cycle. Other crops with a lower profitability, like sugarcane, do not allow more than 3-4 releases in most years.

Pest/Parasitoid Simulation Model. Parasitoid-pest simulation models are developed on specialized software programs, based on biological data about the pest and its natural enemies. These models for Trichogramma can be developed in Brazil, because the number of basic researches involving this parasitoid along these 20 years has been expressive. However, lack of simulation specialists prevents us from having these models at our disposal.

The need of a group of specialists in order to develop an applied biological control program is evident. Thus, a taxonomist, a biologist, an ecologist, a specialist on agrochemicals, an entomologist-economist, and a computer science specialist must work together. Evidently, in this case, the chances of obtaining success are much higher than if the program is developed only by an entomologist with a general formation.

\section{Studies with Trichogramma in Brazil}

The research on Trichogramma has spread throughout Brazil, resulting in the appearance of other study groups involved with this subject. However, except by some cases, like the use of T. pretiosum to control Tuta absoluta (Meirick), the releases on cotton by Embrapa Algodão, in Paraíba State, the sporadic use of T. atopovirilia Oatman \& Platner and T. pretiosum to control Spodoptera frugiperda (J.E. Smith) in corn and Plutella xylostella L. in cabbage, the project has not reached large areas, due to the difficulty in transferring the technology, and particularly to the lack of good quality insects available for the farmer.

The volume of information and results are very interesting and liable to be used in crops such as cotton, soybean, sugarcane, tomato and other vegetables, corn, stored grain pests, etc. In addition, Garcia (1998) and Molina (2003) demonstrated the potential of use of T. pretiosum in citrus to control E. aurantiana (Lima), the citrus fruit borer; in avocado, the parasitoid is being studied to control Stenoma catenifer Wals. (Hohmann \& Meneguim 1993); in agricultural crops, $T$. pretiosum, T. atopovirilia, and T. galloi have shown the greatest potential of use in our country.

Corn. In both sweet and commercial corn cultivars, results are better on $H$. zea control, since the egg-laying scales of $S$. frugiperda, disposed in layers, make parasitism difficult (Sá
1991, Beserra 2000). Trichogramma releases have been recommended in areas attacked by S. frugiperda (Cruz et al. 1999), with good results.

Several basic studies have been performed to control $H$. zea with T. pretiosum (Sá \& Parra 1994a), with natural parasitism by T. pretiosum reaching 95\% (Sá \& Parra 1994b). When releases are recommended at the rate of 11 parasitoids per H. zea egg, and taking into account the parasitoid's dispersal, such releases should be done at a great number of points per hectare (Sá et al. 1993). Three releases of 100 thousand T. pretiosum adults/ha reduce $26 \%$ of $H$. zea damage on corn (Sá 1991). Rivero (1992) also conducted basic researches with $H$. zea versus $T$. pretiosum, indicating that the parasitoid could yield from 4.8 to 8.5 times more generations than the corn earworm. Beserra (2000) observed that egg parasitism in S. frugiperda is low and concentrated at the bottom and medium parts of the plant. Although occurring in smaller numbers in the field, $T$. atopovirilia shows higher parasitism capacity than $T$. pretiosum. According to this author, the presence of scales on $S$. frugiperda egg masses is the main factor that contributes to decrease T. atopovirilia and T. pretiosum potential of parasitism. Also, the distribution of eggs in layers prevents egg parasitism in the lower parts by T. atopovirilia (Table 1).

Table 1. Parasitism capacity of T. atopovirilia in a shadenetting structure on $S$. frugiperda egg masses with different physical characteristics (Beserra 2000).

\begin{tabular}{lc}
\hline Mass & Parasitism (\%) \\
\hline One layer & 66.2 \\
Two layers & 45.2 \\
Three layers & 40.1 \\
\hline
\end{tabular}

Cotton. Entomologists at Embrapa Algodão, in Campina Grande, PB, have conducted excellent works with $T$. pretiosum to control the cotton leafworm, A. argillacea. The potential to use $T$. pretiosum has also been demonstrated for $H$. virescens (J.R.P. Parra, unpublished). At Embrapa, a system adapted from the Colombian model for rearing the parasitoid on S. cerealella eggs has been adopted (Almeida 1996).

The pioneering works in Brazil were conducted by Bleicher (1985) involving three $T$. pretiosum populations aimed at controlling $A$. argillacea, with parasitoids reared on $A$. kuehniella.

Life table results confirmed the biological data, and the $T$. pretiosum population from Iguatu, CE, was the most aggressive (Bleicher \& Parra 1990a, 1991). Temperature requirement studies were also carried out, showing that the biology of T. pretiosum is influenced by the collection locality (origin). Between 2.7 and 2.9 Trichogramma generations were observed for each generation of A. argillacea (Bleicher \& Parra 1989, 1990b). The parasitoids' longevity was higher when they were given a chance to parasitize and when they were fed pure honey.

Sugarcane. The bulk of the information about Trichogramma is concentrated on this crop. Some of the studies deal with: identification of predominant species in Brazil - especially $T$. 
galloi Zucchi and T. distinctum Zucchi - by conventional (Zucchi et al. 1991, Zucchi \& Monteiro 1997) and molecular methods (Ciociola Jr. et al. 2001a,b); temperature (Parra et al. 1991) and humidity requirements (Parra \& Sales 1994); most suitable factitious host (Gomes \& Parra 1998); different developmental stages of the parasitoid's biological cycle (Cônsoli et al. 1999); spatial and temporal distribution of $D$. saccharalis eggs and their parasitism by T. galloi (Micheletti 1987); effect of natural and fastitious host egg age on the development and parasitism of $T$. galloi and T. distinctum (Lopes \& Parra 1991); effect of constant and fluctuating temperatures on the development and parasitism of $T$. galloi (Cônsoli \& Parra 1995a,b); photoperiod effect on the biology of T. galloi (Cônsoli \& Parra 1994); artificial infestation methodology of $D$. saccharalis eggs for studies with Trichogramma (Lopes et al. 1989); determination of the parasitoid's range of action $(10 \mathrm{~m})$ and number of $T$. galloi to be released per D. saccharalis egg (1.6:1) (Lopes 1988); and efficiency of $T$. galloi individually or in association with $C$. flavipes in field evaluations (Botelho et al. 1999). These were followed by parasitism studies of T. galloi in sugarcane varieties, conducted at different row spacing (Botelho et al. 1995a,b). Studies on the selectivity of chemical products to T. galloi were also conducted (Cônsoli et al. 2001), as well as studies on release techniques (Pinto 1999).

Field results were outstanding; the association of one release of Cotesia flavipes (Cameron) with three releases of $T$. galloi was the most efficient, resulting in a reduction of the infestation intensity of $60.2 \%$ relative to the control (Table 2 ). This treatment (three releases of 200 thousand T. galloi per week and one release of 6 thousand $C$. flavipes) was much superior to the control, i.e., better than $C$. flavipes individually, because in this case, the reduction in relation to the area where releases were made was only $16.1 \%$. These results attest the feasibility of using T. galloi, especially in areas where egg predation is low and $C$. flavipes is not well adapted.

Soybean. In some regions in Brazil, egg parasitism of $A$. gemmatalis by T. pretiosum is sometimes higher than $90 \%$ (Zachrisson 1997). This author showed that the proportion of 5.3 parasitoids per $A$. gemmatalis egg allows a high parasitism rate, regardless of the phenological stage of soybean.

Aspects related to temperature requirements, plant phenology, parasitism, and strain effect on parasitism, among others, were also studied. The dispersal ability of T. pretiosum to parasitize $A$. gemmatalis eggs in $24 \mathrm{~h}$ is $8 \mathrm{~m}$ and corresponds to a dispersal area of $77 \mathrm{~m}^{2}$ (Fig. 2). Thus, the release of $T$. pretiosum to control A. gemmatalis should be performed in

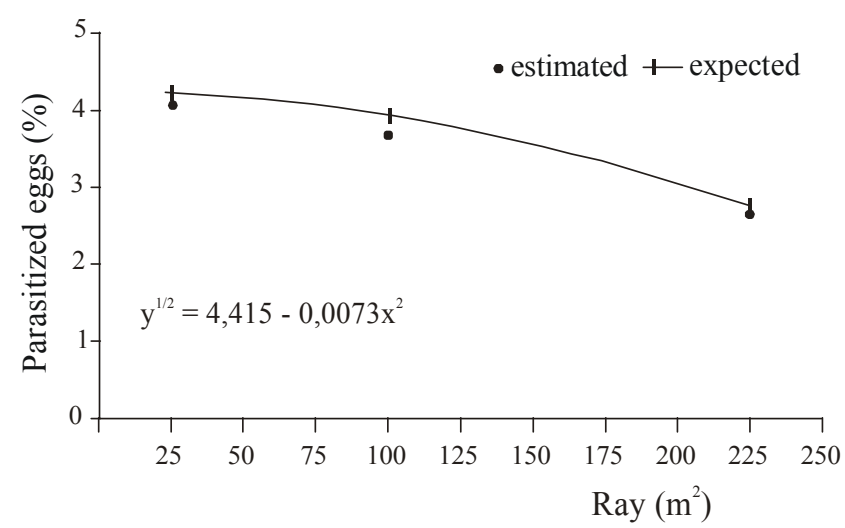

Figure 2. Mathematical relation between the dispersal range of T. pretiosum and the number of $A$. gemmatalis eggs parasitized (Zachrisson \& Parra 1998).

130 points per ha, with a control efficiency of $64.8 \%$ (Zachrisson \& Parra 1998). Its potential to control $A$. gemmatalis is rather great, since five Trichogramma species have already been collected parasitizing this pest (Foerster \& Avanci 1999, Avanci 2004).

Stored Grain. Studies conducted by Inoue (1997) demonstrated the potential of T. pretiosum to control S. cerealella in stored corn, both in bulk and on the ear. The storehouses, being stable ecosystems, experience high temperatures, what favors parasitism, as reported by Inoue \& Parra (1998), who found $97.6 \%$ of the females parasitizing at $30^{\circ} \mathrm{C}$.

The parasitoids released in the grain mass are capable of parasitizing $S$. cerealella eggs at depths of up to $40 \mathrm{~cm}$, and the percentage of parasitism decreases, on average, $1.9 \%$ for each $\mathrm{cm}$ of depth in the corn grain mass. For greater control efficiency, the release should be made in the beginning of the attack by the moth, at a rate of 12 parasitoids per $S$. cerealella egg. For ear corn, releasing T. pretiosum is efficient to control S. cerealella, reducing the population of adult moths by $60.7 \%$ and the damage caused to stored ears in screened warehouses by $63.1 \%$. The association of $T$. pretiosum with Bracon hebetor Say did not result in advantages in the control of S. cerealella in comparison with the release of T. pretiosum alone; however, numerically there is a tendency for greater efficiency when both species of parasitoids work in association (Inoue 1997) (Table 3).

Tomato. Studies with the moths - T. absoluta and Phthorimaea operculella (Zeller) - and the borer $-H$. zea and N. elegantalis - in tomato have shown the feasibility to use T. pretiosum in

Table 2. Percentage of reduction in infestation intensity (II \%) by D. saccharalis after using different biological control tactics in sugarcane. Brasilândia, MS (Botelho et al. 1999).

\begin{tabular}{lcc}
\hline Treatments & Number released/ha & II \% Reduction \\
\hline T. galloi (one release) + C. flavipes (one release) & $200,000+6,000$ & 27.0 \\
T. galloi (two releases) + C. flavipes (one release) & $200,000+6,000$ & 33.4 \\
T. galloi (three releases) + C. flavipes (one release) & $200,000+6,000$ & 60.2 \\
C. flavipes (one release) - control 1 & 6,000 & 16.1 \\
No release - control 2 & - & 0.0 \\
\hline
\end{tabular}


Table 3. Damage percentage in stored corn grain due to the attack of S. cerealella after parasitoid release (Inoue 1997).

\begin{tabular}{lcccc}
\hline Treatments & $\begin{array}{c}\text { Parasitoid : pest } \\
\text { ratio released }\end{array}$ & $\begin{array}{c}\text { Pest population } \\
\text { reduction }(\%)\end{array}$ & $\begin{array}{c}\text { Damage } \\
\text { reduction (\%) }\end{array}$ & $\begin{array}{c}\text { Damaged grain } \\
(\%)\end{array}$ \\
\hline T. pretiosum & $1: 5$ & 60.7 & 63.1 & 7.7 \\
T. pretiosum + B. hebetor & $1: 5+1: 112$ & 69.4 & 70.1 & 6.0 \\
No release - control & - & - & - & 18.9 \\
\hline
\end{tabular}

this vegetable crop. Excellent results have been obtained in the greenhouse, in sprawling, and in staked tomatoes.

In the greenhouse, results are very good for T. absoluta, but it is necessary to select strains to control $N$. elegantalis, the tomato fruit borer; weekly releases are recommended, at the rate of 6.4 parasitoids per T. absoluta egg, based on leaflet samplings. A control of $87 \%$ with $T$. pretiosum releases in relation to the $42 \%$ of control was obtained with the growth regulator lufenuron (J.R.P. Parra, unpublished).

In practical terms, the excellent results obtained at Vale do São Francisco, Pernambuco State, in the control of T. absoluta atest the feasibility to use this parasitoid. There are many other basic studies with T. pretiosum for the control of P. operculella and T. absoluta, based on biological studies (Pratissoli \& Parra 2000a), fertility life table (Pratissoli \& Parra 2000b), and on parasitism capacity (Pratissoli 1995). It has also been demonstrated that cluster analysis is a suitable method for selecting Trichogramma strains (Pratissoli \& Parra 2001).

Several selectivity studies on products used in the crop have been conducted (Cônsoli et al. 1998, Carvalho et al. 1999). Papa (1998) recorded excellent results in staked tomato by releasing 800 thousand parasitoids (T. pretiosum) per ha, with a control efficiency similar to the use of insecticides.

For H. zea in processing tomato, Moreira (1999) achieved a control efficiency of $83 \%$ in the field, releasing 400 thousand T. pretiosum parasitoids per ha, at weekly intervals, with variable results depending on the strain's origin.

\section{Final Considerations}

Twenty years after a steady flow of Trichogramma studies in Brazil began, there are still some problems to be solved. One of them is the availability of insects for the farmer, which is beginning to be resolved presently as insect-selling companies arise, similarly to what is happening in other countries in the world. Even field assays, which for many were considered insufficient, will be improved with such availability of insects. One of the great worldwide hindrances to the development of biological control programs is the technology transfer provided to the user; this worldwide problem could be solved by the above-mentioned companies themselves. It becomes clear that, in these cases, production scale changes would have to be implemented as compared to laboratory research needs. For this reason, it is essential that constant quality control should be maintained by insect suppliers, always under the supervision and follow-up of Research Institutions and Universities.

However, the high volume of information on Trichogramma species, obtained from books, bulletins, congress abstracts, dissertations, theses, and national and international periodicals, has allowed great advances in the area of biological control and, especially, because this study model has served as a basis for researches with other parasitoids and predators in Brazil. Trichogramma study groups were formed in several states, such as Espírito Santo, Rio Grande do Sul, Paraná, Rio de Janeiro, Mato Grosso, Santa Catarina, Paraíba, Pernambuco, Minas Gerais, and groups also found motivation elsewhere in Latin America countries, such as in Chile, Uruguay, Argentina, Paraguay, and Panama.

Concurrently (and in this maybe consists the high proceeds of all basic research that has been developed), cutting-edge studies were conducted in the area of "in vitro" production of Trichogramma (Parra \& Cônsoli 1992, Cônsoli \& Parra 1999, Cônsoli \& Parra 2002) and other parasitoids (Magro \& Parra 2004), placing Brazil in the vanguard of this type of study, as a leader in Latin America, and putting the country at a level playing field with developed countries. These studies will enable advances in the area of hosts/natural enemies' relations, allowing greater development in a short period of time, including rearing techniques for parasitoids and predators.

Although still timidly, more intense use of T. pretiosum is being made to control T. absoluta in tomato, both in field areas and under protected cropping, P. xylostella in cabbage, based on results by Barros (1998), and in corn areas with $T$. atopovirilia and T. pretiosum to control S. frugiperda, though in this case with the previously indicated limitations. In Brazil, between 5 and 10 billion Trichogramma wasps are produced annually, and released in 60,000 ha of corn and in 1,000 to 1,200 ha of tomato and crucifers (cabbage), with a perspective for significant increase in a very near future.

The potential of use in sugarcane, cotton, vegetables, fruit trees, and soybean, among others, as well as the other advantages indicated, give a dimension of the work that has been performed and the progress that has been accomplished along 20 years of studies with Trichogramma spp. in Brazil.

\section{Literature Cited}

Almeida, R.P. de. 1996. Biotecnologia de produção massal de Trichogramma spp. através do hospedeiro alternativo Sitotroga cerealella. Campina Grande, PB, EMBRAPA, CNPA, Circular Técnica n. 19, 36p.

Avanci, M.R.F. 2004. Espécies de Trichogramma Westwood (Hymenoptera: Trichogrammatidae) que ocorrem em ovos de Anticarsia gemmatalis Hübner (Lepidoptera: Noctuidae) no Sudeste do Paraná: Parasitismo natural, bioecologia, exigências térmicas e estocagem em baixas temperaturas. Ph.D. thesis, Curitiba, 
Universidade Federal do Paraná, 116p.

Barros, R. 1998. Efeito de cultivares de repolho Brassica oleracea var. capitata (L.) na biologia da traça-dascrucíferas, Plutella xylostella (L., 1758) e do parasitóide Trichogramma pretiosum Riley, 1879. Ph.D. thesis, Piracicaba, ESALQ, Universidade de São Paulo, 98p.

Bernardi, E.B., M.L. Haddad \& J.R.P. Parra. 2000. Comparison of artificial diets for rearing Corcyra cephalonica (Stainton, 1865) (Lep., Pyralidae) for Trichogramma mass production. Rev. Bras. Biol. 60: 45-52.

Beserra, E.B. 2000. Biologia, etologia e capacidade de parasitismo de Trichogramma spp. visando ao controle de Spodoptera frugiperda (J.E. Smith, 1797). Ph.D. thesis, Piracicaba, ESALQ, Universidade de São Paulo, $132 \mathrm{p}$.

Bleicher, E. 1985. Biologia e exigências térmicas de populações de Trichogramma (Hym.: Trichogrammatidae). Ph.D. thesis, Piracicaba, ESALQ, Universidade de São Paulo, 80p.

Bleicher, E. \& J.R.P. Parra. 1989. Espécies de Trichogramma parasitóides de Alabama argillacea. I. Biologia de três populações. Pesq. Agropec. Bras. 24: 929-940.

Bleicher, E. \& J.R.P. Parra. 1990a. Espécies de Trichogramma parasitóides de Alabama argillacea. II. Tabela de vida de fertilidade e parasitismo de três populações. Pesq. Agropec. Bras. 25: 207-214.

Bleicher, E. \& J.R.P. Parra. 1990b. Espécies de Trichogramma parasitóides de Alabama argillacea. III. Determinação das exigências térmicas de três populações. Pesq. Agropec. Bras. 25: 215-219.

Bleicher, E. \& J.R.P. Parra. 1991. Efeito do hospedeiro de substituição e da alimentação na longevidade de Trichogramma sp. Pesq. Agropec. Bras. 26: 1845-1850.

Botelho, P.S.M., J.R.P. Parra, E.A. Magrini, M.L. Haddad \& L.C.L. Resende. 1995a. Parasitismo de ovos de Diatraea saccharalis (Fabr., 1794) (Lep., Pyralidae) por Trichogramma galloi Zucchi, 1986 (Hym., Trichogrammatidae) em duas variedades de cana-deaçúcar conduzidas em dois espaçamentos de plantio. Rev. Bras. Entomol. 39: 591-595.

Botelho, P.S.M., J.R.P. Parra, E.A. Magrini, M.L. Haddad \& L.C.L. Resende. 1995b. Parasitismo de ovos de Diatraea saccharalis (Fabr.) por Trichogramma galloi Zucchi, em diferentes variedades de cana-de-açúcar. An. Soc. Entomol. Brasil 24: 141-145.

Botelho, P.S.M., J.R.P. Parra, J.F.C. Neto \& C.P.B. Oliveira. 1999. Associação do parasitóide de ovos Trichogramma galloi Zucchi (Hymenoptera:
Trichogrammatidae) e do parasitóide larval Cotesia flavipes (Cam.) (Hymenoptera: Braconidae) no controle de Diatraea saccharalis (Fabr.) (Lepidoptera: Crambidae) em cana-de-açúcar. An. Soc. Entomol. Brasil 28: 491-496.

Butler Jr., G.D. \& J.D. Lopez. 1980. Trichogramma pretiosum: development in two hosts in relation to constant and fluctuating temperatures. Ann. Entomol. Soc. Am. 73: 671-673.

Calvin, D.D., M.C. Knapp, S.M. Welch, F.L. Poston \& R.J. Elzinga. 1984. Impact of environmental factors on Trichogramma pretiosum reared on south western corn borer eggs. Environ. Entomol. College Park 13: 774-780.

Carvalho, G.A., J.P.R.P. Parra \& G.C. Baptista. 1999. Ação residual de alguns inseticidas pulverizados em plantas de tomateiro sobre duas linhagens de Trichogramma pretiosum Riley, 1879 (Hymenoptera: Trichogrammatidae) em casa-de-vegetação. Ciênc. Agrotec. 23: 771-776.

Ciociola Jr., A.I., R.A. Zucchi \& R. Stouthamer. 2001a. Molecular key to seven Brazilian species of Trichogramma (Hymenoptera: Trichogrammatidae) using sequence of the IT S2 region of restriction analysis. Neotrop. Entomol. 30: 259-261.

Ciociola Jr., A.I., R.A. Zucchi \& R. Stouthamer. 2001 b. Detecção de Wolbachia em uma população telítoca de Trichogramma atopovirilia Oataman \& Platner (Hymenoptera: Trichogrammatidae) via PCR com o primer específico wsp. Neotrop. Entomol. 30: 489-491.

Ciociola Jr., A.I., R.B. Querino, R.A. Zucchi \& R. Stouthamer. 2001c. Molecular tool for identification of closely related species of Trichogramma (Hymenoptera: Trichogrammatidae): T. rojasi Nagaraja \& Nagakarti and T. lasallei Pinto. Neotrop. Entomol. 30: 575-578.

Cônsoli, F.L. \& J.R.P. Parra. 1994. Efeito do fotoperíodo na biologia de Trichogramma galloi Zucchi. An. Soc. Entomol. Brasil 23: 467-472.

Cônsoli, F.L. \& J.R.P. Parra. 1995a. Effect of constant and alternating temperatures on Trichogramma galloi Zucchi (Hymenoptera: Trichogrammatidae) biology. I. Development and thermal requirements. J. Appl. Entomol. 119:415-418.

Cônsoli, F.L. \& J.R.P. Parra. 1995b. Effect of constant and alternating temperatures on Trichogramma galloi Zucchi (Hymenoptera: Trichogrammatidae) biology. II. Parasitism capacity and longevity. J. Appl. Entomol. 119: 667-670.

Cônsoli, F.L. \& J.R.P. Parra. 1999. In vitro rearing of parasitoids: constraints and perspectives. Trends Entomol. 2: 19-32. 
Cônsoli, F.L. \& J.R.P. Parra. 2002. Criação in vitro de parasitóides e predadores, p.239-275. In J.R.P Parra, P.S.M. Botelho, B.S. Corrêa-Ferreira \& J.M.S. Bento (eds.) Controle biológico no Brasil - parasitóides e predadores. Piracicaba, Ed. Manole, 609p.

Cônsoli, F.L., J.R.P. Parra \& S.A. Hassan. 1998. Side-effects of insecticides used in tomato fields on the egg parasitoid Trichogramma pretiosum Riley (Hym., Trichogrammatidae), a natural enemy of Tuta absoluta (Meyrick) (Lep., Gelechiidae). J. Appl. Entomol. 122: 43-47.

Cônsoli, F.L., M.M. Rossi \& J.R.P. Parra. 1999. Developmental time and characteristics of the immature stages of Trichogramma galloi and T. pretiosum (Hymenoptera, Trichogrammatidae). Rev. Bras. Entomol. 43:271-275.

Cônsoli, F.L., P.S.M. Botelho \& J.R.P. Parra. 2001. Selectivity of insecticides to the egg parasitoid Trichogramma galloi Zucchi, 1986 (Hym., Trichogrammatidae). J. Appl. Entomol. 125: 37-43.

Cruz, I., M.L.C. Figueiredo \& M.J. Matoso. 1999. Controle biológico de Spodoptera frugiperda utilizando o parasitóide de ovos Trichogramma. Sete Lagoas, MG, EMBRAPA, CNPMS, Circ. Técn. n. 30, 40p.

Dahlan, A.N. \& G.Gordh. 1996. Development of Trichogramma australicum Girault (Hymenoptera: Trichogrammatidae) on Helicoverpa armigera (Hübner) eggs (Lepidoptera: Noctuidae). Austr. J. Entomol. 35: 337-344.

Degrande, P.E., P.R. Reis, G.A. Carvalho \& L.C. Belarmino. 2002. Metodologia para avaliar o impacto de pesticidas sobre inimigos naturais, p.71-93. In J.R.P Parra, P.S.M. Botelho, B.S. Corrêa-Ferreira \& J.M.S. Bento (eds.). Controle biológico no Brasil - parasitóides e predadores. Piracicaba, Ed. Manole, 906p.

Doutt, R.L. 1959. The biology of parasitic Hymenoptera. Ann. Rev. Entomol. 4: 161-182.

Flanders, S.E. 1927. Biological control of the codling moth (Carpocapsa pomonella). J. Econ. Entomol. 20: 644.

Foerster, L.A. 2002. Seletividade de inseticidas a predadores e parasitóides, p.95-114. In Parra, J.R.P., P.S.M. Botelho, B.S. Corrêa-Ferreira \& J.M.S. Bento (eds.), Controle biológico no Brasil - parasitóides e predadores. Piracicaba, Ed. Manole, 906p.

Foerster, L.A. \& M.R.F. Avanci. 1999. Egg parasitoids of Anticarsia gemmatalis Hübner (Lepidopera: Noctuidae) in soybeans. An. Soc. Entomol. Brasil 28: 545-548.

Garcia, M.S. 1998. Bioecologia e potencial de controle biológico de Ecdytolopha aurantiana (Lima, 1927) a (Lepidoptera: Tortricidae), o bicho-furão-dos-citros, através de
Trichogramma pretiosum Riley, 1879. Ph.D. thesis, Piracicaba, ESALQ, Universidade de São Paulo, 118p.

Gomes, J.G. 1963. Histórico do combate biológico no Brasil. Primeiro Simpósio Brasileiro Sobre Combate Biológico. Bol. Inst. Agric. 21: 89-97.

Gomes, S.M. 1997. Comparação de três hospedeiros alternativos para criação e produção massal de Trichogramma pretiosum Riley, 1879. M.Sc. dissertation, Piracicaba, ESALQ, Universidade de São Paulo, 106p.

Gomes, S.M. \& J.R.P. Parra. 1998. The parasitization as a tool for factitious host selection for Trichogramma galloi Zucchi and T. pretiosum Riley. Mitteillungen aus der Biologischen Bundesanstalt für Land-und Forstwirtschaft 356: 13-23.

Glenn, D.C. \& A.A. Hofmann. 1997. Developing a commercially viable system for biological control of light brown apple moth (Lepidoptera: Tortricidae) in grapes using endemic Trichogramma (Hymenoptera: Trichogrammatidae). J. Econ. Entomol. 90:370-382.

Haji, F.N.P., L. Prezotti, J.S. Carneiro \& J.A. Alencar. 2002. Trichogramma pretiosum para o controle de pragas no tomateiro industrial, p.477-494. In J.R.P. Parra, P.S.M. Botelho, B.S. Corrêa-Ferreira \& J.M.S. Bento (eds.), Controle biológico no Brasil - parasitóides e predadores. Piracicaba, Ed. Manole, 609p.

Hassan, S.A. 1988. Guideline for testing the side effect of pesticides on the egg parasite Trichogramma cacocciae. IOBC / WPRS B. 11:3-18.

Hassan, S.A. 1997. Seleção de espécies de Trichogramma para uso em programas de controle biológico, p.183-205. In J.R.P. Parra \& R.A. Zucchi (eds.), Trichogramma e o controle biológico aplicado. Piracicaba, FEALQ, 324p.

Hassan, S.A., E. Kolher \& W.M. Rost. 1988. Mass production and utilization of Trichogramma: 1. Control of the codling moth, Cydia pomonella and the summer fruit tortrix moth Adoxophyes orana (Lep.: Tortricidae). Entomophaga 33: 413-420.

Hohmann, C.L. \& A.M. Meneguim. 1993. Observações preliminares sobre a ocorrência da broca do abacate Stenoma catenifer Wals. no estado do Paraná. An. Soc. Entomol. Brasil 22: 417-419.

Inoue, M.S.R. 1997. Bioecologia da traça-dos-cereais Sitotroga cerealella (Olivier, 1819) e seu controle biológico em milho armazenado com Trichogramma pretiosum Riley, 1879 e Bracon hebetor Say, 1857. M.Sc. dissertation, Piracicaba, ESALQ, Universidade de São Paulo, 101p.

Inoue, M.S.R. \& J.R.P. Parra. 1998. Efeito da temperatura 
no parasitismo de Trichogramma pretiosum Riley, 1879 sobre ovos de Sitotroga cerealella (Olivier, 1819). Sci. Agr. 55: 222-226.

Lenteren, J.C. van. 2000. Success in biological control of arthropods by augmentation of natural enemies, p.77103. In T.S. Bellows Jr. \& S. Wratten (eds.), Biological control. Measures of success. Dordrecht, Kluwer Acad. Publish., 448p.

Lewis, W.J., D.A. Nordlund, H.R. Gross Jr., W.D. Perkins \& J. Voegelé. 1976. Production and performance of Trichogramma reared in eggs of Heliothis zea and other hosts. Envirom. Entomol. 5: 449-452.

Lopes, J.R.S. 1988. Estudos bioetológicos de Trichogramma galloi Zucchi, 1986 (Hym., Trichogrammatidae) para o controle de Diatraea saccharalis (Fabr., 1794) (Lep., Pyralidae). M.Sc. dissertation, Piracicaba, ESALQ, Universidade de São Paulo, 141p.

Lopes, J.R.S. \& J.R.P. Parra. 1991. Efeito da idade do ovo do hospedeiro natural e alternativo no desenvolvimento e parasitismo de duas espécies de Trichogramma. Rev. Agr. 66: 221-244.

Lopes, J.R.S., J.R.P. Parra, J. Justi Jr. \& H.N. Oliveira. 1989. Metodologia para infestação artificial de ovos de Diatraea saccharalis (Fabr., 1794) em cana-de-açúcar visando estudos com Trichogramma spp. Anais da ESALQ 46: 375-390.

Lund, H.O. 1934. Some temperature and humidity relations of two races of Trichogramma minutum Riley (Hym.: Chalcididae). Ann. Entomol. Soc. Am. 27: 324-340.

Magro, S.R. \& J.R.P. Parra. 2004. Comparison of artificial diets for rearing Bracon hebetor Say (Hymenoptera: Braconidae). Biol. Control 29: 341-347.

Micheletti, S.M.F.B. 1987. Distribuição espacial e temporal de ovos de Diatraea saccharalis (Fabr., 1794) (Lep., Pyralidae) e seu parasitismo por Trichogramma sp. (Hym., Trichogrammatidae). M.Sc. dissertation, Piracicaba, ESALQ, Universidade de São Paulo, 95p.

Mills, N., C. Pickel, S. Mansfield, S. Mcdougall, R. Buchner, J. Caprile, J. Edstrom, R. Elkins, J. Hasey, K. Kelley, B. Krueger, B. Olson \& R. Stocker. 2000. Mass releases of Trchogramma wasps can reduce damage from codling moth. Cal. Agric. 56: 22-25.

Molina, R.M.S. 2003. Bioecologia de duas espécies de Trichogramma para o controle de Ecdytolopha aurantiana (Lima, 1927) (Lepidoptera: Tortricidae) em citros. M.Sc. dissertation, Piracicaba, ESALQ, Universidade de São Paulo, 80p.

Moraes, G.W.G. de, P.G. Brun \& L.A. Soares. 1983. Insetos $\mathrm{x}$ insetos - nova alternativa para o controle de pragas. Ciênc. Hoje 1: 70-77.

Moreira, J.O.T. 1999. Trichogramma pretiosum Riley, 1879 (Hymenoptera: Trichogrammatidae) como agente de controle de Helicoverpa zea (Boddie, 1850) (Lepidoptera: Noctuidae) em tomateiro, Lycopersicon esculentum Mill: Aspectos biológicos e eficiência em campo. Ph.D. thesis, Curitiba, Universidade Federal do Paraná, 84p.

Nagarkati, S. \& H. Nagaraja. 1971. Redescriptions of some known species of Trichogramma, showing the importance of male genitalia as a diagnostic character. Bull. Entomol. Res. 61: 13-31.

Newton, P.J. \& W.J. Odendaal. 1990. Commercial inundative releases of Trichogrammatoidea cryptophlebiae (Hym.: Trichogrammatidae) against Crytophlebia leucotreta (Lep.: Tortricidae) in Citrus. Entomophaga 35: 545-556.

Oatman, E.R. \& G.R. Platner. 1985. Biological control of two avocado pests. Cal. Agric. 39: 21-23.

Papa, G. 1998. Controle integrado de Tuta absoluta (Meyrick, 1917) com emprego de Trichogramma pretiosum Riley, 1879, inseticidas biológicos e fisiológicos. M.Sc. dissertation, Piracicaba, ESALQ, Universidade de São Paulo, 70p.

Parra, J.R.P. 2002. Criação massal de inimigos naturais, p.143164. In J.R.P. Parra, P.S.M. Botelho, B.S. Corrêa-Ferreira \& J.M.S. Bento (eds.), Controle biológico no Brasil parasitóides e predadores. Piracicaba, Ed. Manole, 609p.

Parra, J.R.P. \& F.L. Cônsoli. 1992. "In vitro" rearing of Trichogramma pretiosum Riley, 1879. Ciênc. Cult. 44: 407-409.

Parra, J.R.P., F.L. Cônsoli \& S.A. Hassan. 1997. Effects of the factitious hosts, Ephestia kuehniella and Sitotroga cerealella on the quality of Trichogramma pretiosum. In IV International Conference on Pests in Agriculture, Montpelier (Annales), p. 735-740.

Parra, J.R.P. \& O. Sales Jr. 1994. Biology of Trichogramma galloi reared on natural and factitious hosts under different temperatures and relative humidities. Les Colloques de l'INRA 73: 95-99.

Parra, J.R.P., P.S.M. Botelho, B.S. Corrêa - Ferreira \& J.M.S. Bento. 2002. Controle biológico: Uma visão inter e multidisciplinar, p.125-142. In J.R.P. Parra, P.S.M. Botelho, B.S. Corrêa-Ferreira \& J.M.S. Bento (eds.), Controle biológico no Brasil - parasitóides e predadores. Piracicaba, Ed. Manole, 609p.

Parra, J.R.P. \& R.A. Zucchi. 1986. Uso de Trichogramma no controle de pragas, p.54-57. In O. Nakano, S. Silveira Neto, J.R.P.Parra \& R.A. Zucchi (orgs.), Atualização sobre métodos de controle de pragas. Piracicaba, ESALQ, 129p. 
Parra, J.R.P. \& R.A. Zucchi. 1997. (eds.), Trichogramma e o controle biológico aplicado. Piracicaba, FEALQ, 324 p.

Parra, J.R.P., R.A. Zucchi, S. Silveira Neto \& M.L. Haddad. 1991. Biology and thermal requirements of Trichogramma galloi Zucchi and T. distinctum Zucchi, on two factitious hosts. Colloques de 1'INRA 56: 81-84

Pinto, A.S. 1999. Comparação de técnicas de liberação e parasitismo de Trichogramma galloi Zucchi, 1986 em infestações de Diatraea saccharalis (Fabr., 1794) prejudiciais à cana-de-açúcar. Ph.D. thesis, Piracicaba, ESALQ, Universidade de São Paulo, 83p.

Pinto, J.D. 1999. Systematics of the North American species of Trichogramma Westwood (Hymenoptera: Trichogrammatidae) Mem. Entomol. Soc. Wash. 22: 1187.

Pratissoli, D. 1995. Bioecologia de Trichogramma pretiosum Riley, 1879, nas traças, Scrobipalpuloides absoluta (Meyrick, 1917) e Phthorimaea operculella (Zeller, 1873), em tomateiro. Ph.D. thesis, Piracicaba, ESALQ, Universidade de São Paulo, 135p.

Pratissoli, D. \& J.R.P. Parra. 2000a. Desenvolvimento e exigências térmicas de Trichogramma pretiosum Riley, criado em duas traças do tomateiro. Pesq. Agropec. Bras. 35: $1281-1288$.

Pratissoli, D. \& J.R.P. Parra. 2000b. Fertility life table of Trichogramma pretiosum (Hym., Trichogrammatidae) in eggs of Tuta absoluta and Phthorimaea operculella (Lep., Gelechiidae) at different temperatures. J. Appl. Entomol. 124: 339-342.

Pratissoli, D. \& J.R.P. Parra. 2001. Seleção de linhagens de Trichogramma pretiosum Riley (Hymenoptera, Trichogrammatidae) para o controle das traças Tuta absoluta (Meyrick) e Phthorimaea operculella (Zeller) (Lep., Gelechiidae). Neotrop. Entomol. 30: 277-282.

Prezotti, L., J.R.P. Parra, R. Vencovsky, A.S.G. Coelho \& I. Cruz. 2004. Effect of the size of the founder population on the quality of sexual populations of Trichogramma pretiosum, in laboratory. Biol. Control 30: 174-180.

Querino, R.B. \& R.A. Zucchi. 2001. Espécies de Trichogramma - coleção da ESALQ www.ciagri.usp.br/ let/taxon.htm

Querino, R.B.\& R.A. Zucchi. 2002a. Relative warp analysis to study morphological variations in the genital capsule of Trichogramma pretiosum Riley (Hymenoptera: Trichogrammatidae). Neotrop. Entomol. 31:217-224.

Querino, R.B.\& R.A. Zucchi. 2002b. Intraspecific variation in Trichogramma bruni Nagaraja, 1983 (Hymenoptera: Trichogrammatidae) associated with different hosts. Braz. J. Biol. 62: 665-679.

Querino, R.B. \& R.A. Zucchi. 2003a. Six new species of Trichogramma Westwood (Hymenoptera: Trichogrammatidae) from a Brazilian forest reserve. Zootaxa 134: 1-11.

Querino, R.B. \& R.A. Zucchi. 2003b. New species of Trichogramma Westwood (Hymenoptera: Trichogrammatidae) associated with lepidopterous eggs in Brazil. Zootaxa163: 1-10.

Rivero, R.C. 1992. Biologia e exigências térmicas de Helicoverpa zea (Boddie, 1850) e do seu parasitóide Trichogramma pretiosum Riley, 1879. Ph.D. thesis, Piracicaba, ESALQ, Universidade de São Paulo, 54p.

Sá, L.A.N. 1991. Bioecologia de Trichogramma pretiosum Riley, 1879, visando avaliar o seu potencial para o controle de Spodoptera frugiperda (J.E. Smith,1797) e Helicoverpa zea (Boddie, 1850) em milho. Ph.D. thesis, Piracicaba, ESALQ, Universidade de São Paulo, 107p.

Sá, L.A.N. \& J.R.P. Parra. 1994a. Biology and parasitism of Trichogramma pretiosum Riley (Hym., Trichogrammatidae) on Ephestia kuehniella (Zeller) (Lep., Pyralidae) and Heliothis zea (Boddie) (Lep., Noctuidae) eggs. J. Appl. Entomol. 118: 38-43.

Sá, L.A.N. \& J.R.P. Parra. 1994b. Natural parasitism of Spodoptera frugiperda and Helicoverpa zea (Lepidoptera, Noctuidae) eggs in corn by Trichogramma pretiosum (Hymenoptera: Trichogrammatidae) in Brazil. Fla. Entomol. 77: 185-188.

Sá, L.A.N. \& J.R.P. Parra \& S. Silveira Neto 1993. Capacidade de dispersão de Trichogramma pretiosum Riley, 1879 para controle de Helicoverpa zea (Boddie, 1850) em milho. Sci. Agr. 50: 226-231.

Smith, S.M. 1996. Biological control with Trichogramma: advances, successes and potential of their use. Annu. Rev. Entomol. 41:375-406.

Stouthamer, R., J.D. Pinto, G.R. Platner \& R.F. Luck. 1990. Taxonomic status of thelytokous forms of Trichogramma (Hymenoptera: Trichogrammatidae). Ann. Entomol. Soc. Am. 83:475-481.

Volkoff, A.N., J. Daumal, P. Barry, M.C. François, N. Hawlitzky \& M.M. Rossi. 1995. Development of Trichogramma cacoeciae Marchal (Hymenoptera: Trichogrammatidae): Time table and evidence for a single larval instar. Int. J. Insect Morphol. Embryol. 24: 459-466.

Wajnberg, E. \& S.A. Hassan. 1994. Biological control with egg parasitoids. IOBC-CAB International, 286p. 
Zachrisson, B.S.A. 1997. Bioecologia de Trichogramma pretiosum Riley, 1879, para o controle de Anticarsia gemmatalis Hübner, 1818, na cultura da soja. Ph.D. thesis, Piracicaba, ESALQ, Universidade de São Paulo, 106p.

Zachrisson, B.S.A. \& J.R.P. Parra. 1998. Capacidade de dispersão de Trichogramma pretiosum Riley, 1879 para o controle de Anticarsia gemmatalis Hübner, 1818 em soja. Sci. Agr. 55: 133-137.

Zucchi, R.A. 1988. New species of Trichogramma (Hym., Trichogrammatidae) associated with sugar cane borer
Diatraea saccharalis (F.) (Lep., Pyralidae) in Brazil. Colloques de l'INRA: 133-140.

Zucchi, R.A. \& R.C. Monteiro. 1997. O gênero Trichogramma na América do Sul, p.41-46. In J.R.P. Parra \& R.A. Zucchi (eds.), Trichogramma e o controle biológico aplicado. Piracicaba, FEALQ, 324p.

Zucchi, R.A., J.R.P. Parra \& S. Silveira Neto. 1991. Trichogramma species associated with some lepidopterous pests in Brazil. Les Colloques de 1'INRA 53: 131-134. 